Research Report No. 15/2013

\title{
The Law and Politics of Unjust Enrichment
}

Dan Priel

Osgoode Hall Law School of York University, dpriel@osgoode.yorku.ca

Follow this and additional works at: http:/ / digitalcommons.osgoode.yorku.ca/clpe

\section{Recommended Citation}

Priel, Dan, "The Law and Politics of Unjust Enrichment" (2013). Comparative Research in Law \& Political Economy. Research Paper No. $15 / 2013$.

http://digitalcommons.osgoode.yorku.ca/clpe/264 


\title{
OSGOODE
}

\section{OSGOODE HALL LAW SCHOOL}

Comparative Research in Law \& Political Economy

RESEARCH PAPER SERIES

Research Paper No. 15/2013

\section{The Law and Politics of Unjust Enrichment}

\author{
Dan Priel
}

\section{Editors:}

Peer Zumbansen (Osgoode Hall Law School, Toronto, Director Comparative Research in Law and Political Economy)

John W. Cioffi (University of California at Riverside)

Leeanne Footman (Osgoode Hall Law School, Toronto, Production Editor) 


\title{
THE LAW AND POLITICS OF UNJUST ENRICHMENT Dan Priel*
}

\begin{abstract}
One of the marked differences between American private law and the private law of the rest of the common law world is the relative lack of interest in restitution in the former compared with the enthusiasm for the subject in the latter. It has recently been suggested that this difference has to do with the impact of legal realism on American law. It was realism's disdain for doctrinal analysis, it is said, which explains why American scholars did not find the largely doctrinally-driven work on restitution very interesting. In this essay I reject this argument as it fails to explain why American scholars did not turn to non-doctrinal restitution scholarship in the same way they have in areas like contract or tort. I offer a different explanation instead, one that derives from the different understanding of the relationship between law and politics among (mainstream) American and Commonwealth lawyers. I argue that it is this difference that explains both why Commonwealth lawyers felt the need to develop restitution as a solution to outstanding problems in other areas of private law, and why American lawyers, in their different political tradition, had little need for restitution to perform this role. I further argue that legal realism does not explain the difference between the U.S. and the Commonwealth on this matter. On the contrary, I argue that the very different fates of legal realism in the U.S. and in other parts of the common law world are explained by the very same underlying differences between law and politics the essay identifies.
\end{abstract}

For a reason which has never been fully explained, the Restatement and, in the next generation, the work of Professors Jack Dawson and George Palmer, failed to stir American lawyers and law schools to anything like the degree to which Goff \& Jones excited those in the Commonwealth of the common law family. ${ }^{1}$

\section{Introduction}

One of the striking differences between American and Commonwealth work on private law is the very different place accorded within them to the law of

\footnotetext{
Assistant Professor, Osgoode Hall Law School, York University. I thank audiences in the London Private Law Discussion Group and the Private Law Theory Workshop, that took place at the University of Toronto Faculty of Law in April 2012 for helpful comments on earlier versions. I also thank two anonymous referees for their comments on the penultimate draft.

${ }^{1}$ Peter Birks, The Foundations of Unjust Enrichment: Six Centennial Lectures (Wellington: Victoria University Press, 2002) at 18-19.
} 
restitution (or unjust enrichment). ${ }^{2}$ In contrast to the Commonwealth where restitution is an area that attracts considerable scholarly attention, in the United States the subject is an academic backwater. Describing the American scene a few years ago John Langbein said that '[i]t is as though a neutron bomb has hit the field-the monuments have been left standing, but the people have been killed off.' ${ }^{3}$ Langbein's explanation for this grim state of affairs puts the blame on the 'terrible toll that the realist movement has inflicted on doctrinal study in post-Second World War USA. ${ }^{4}$ More recently, Chaim Saiman has advanced essentially the same view: 'Commonwealth restitution discourse is largely a product of pre- or antirealist legal thought which generates scepticism from the mainstream

${ }^{2}$ This first sentence already calls for three clarifications. First, while my main focus and examples throughout the essay will come from English law, I believe what I say applies to a certain degree to other Commonwealth jurisdictions. This is because the first impetus for developing this area of law in the Commonwealth came from English lawyers, and also because I think ideas about the relationship between law and politics in England have had considerable influence on the political tradition in the rest of the Commonwealth. Nonetheless, the fact that in recent years different Commonwealth jurisdictions have been carving their own path may be an indication of the decline even in these jurisdictions of the view that private law is a domain that exists outside politics. See the discussion in section II.(b) below. Second, the term private law, and the division between private and public law that it presupposes, is not neutral. In the United States in particular many would argue that in an important sense all law is public law. I use the term therefore only as shorthand for contract, tort, property, and restitution without committing myself to any substantive view on the question in what sense (if any) private law is private. Finally, whether restitution and unjust enrichment form a distinct area of law is a subject of considerable debate, which I intend to avoid here. I trust, however, that the terms restitution and unjust enrichment are familiar enough to identify the subject-matter I am concerned with in this essay.

3 John Langbein, 'The Later History of Restitution' in WR Cornish et al, eds, Restitution Past, Present, and Future: Essays in Honour of Gareth Jones (Oxford: Hart, 1998) 57 at 61.

${ }^{4}$ Ibid at 62. Langbein adds another explanation that has to do with the rise of economic analysis of law. But in a way it is the same explanation, for the rise and success of economic analysis of law (as opposed to other interdisciplinary approaches to law) is the other side of the decline of doctrinal scholarship. I would contend that part of the success of economic analysis of law in the United States has to do with a perception (whether justified or not) among American academic lawyers that it could provide a degree of certainty that legal doctrine does not possess. 
American academic establishment. ${ }^{, 5}$ In essence, the view is that legal realism has led to the decline of respect for the sort of doctrinal analysis that has been the driving force behind restitution in English and Commonwealth law.

This difference between American and English (and perhaps more broadly Commonwealth) legal scholarship is a familiar one, ${ }^{6}$ but as an explanation for the American lack of interest in restitution it suffers from a fundamental flaw: it is true that doctrinal scholarship in the United States is held in low regard, and it is thus not surprising why American legal scholars did not take much interest in the largely doctrinal scholarship that dominates academic work on restitution in the Commonwealth. ${ }^{7}$ But this, of course, is true of restitution just as much as it is true of contract law, tort law and many other areas of law which were once dominated by doctrinal scholarship in the United States. Yet, as even a cursory glance at American law journals reveals, there is wealth of new work in these areas of law, albeit much of it in the style that some Commonwealth scholars call (with a whiff of derision) 'high theory.' So to say that there is little restitution scholarship in the U.S. because restitution scholarship is doctrinal is to beg the real question, namely why there was no growth in non-doctrinal restitution scholarship in the United States that has come to dominate even traditional common law areas like contract and tort law. ${ }^{8}$ Langbein and Saiman's

${ }^{5}$ Chaim Saiman, 'Restitution in America: Why the US Refuses to Join the Global Restitution Party' (2008) 28 Oxford J Legal Stud 99 at 103. This explanation is accepted in Mitchell McInnes, "Resisting Temptations to "Justice" in Robert Chambers et al., eds, Philosophical Foundations of the Law of Unjust Enrichment (Oxford: Oxford University Press, 2009) 100 at 127 [Philosophical Foundations]; Peter Birks, 'Equity, Conscience, and Unjust Enrichment' (1999) 23 Melb U L Rev 1 at 3, n.6.

${ }^{6}$ See PS Atiyah, 'American Tort Law in Crisis' (1987) 7 Oxford J Legal Stud 279 at 280-04 and AWB Simpson, 'Contract: The Twitching Corpse' (1981) 1 Oxford J Legal Stud 265 at 269-71 (1981).

${ }^{7}$ What counts as 'doctrinal' scholarship as opposed to 'theory' may itself be the subject of some contention. What is called 'legal theory' in Allan Beever \& Charles Rickett, 'Interpretive Legal Theory and the Academic Lawyer' (2005) 68 Mod L Rev 320 , I consider doctrinal scholarship. As I see it, the difference is the degree to which the scholar feels compelled to base his arguments on an understanding of legal (especially judicial) materials.

${ }^{8}$ In a different article Saiman added the the lack of prestige of commercial law in America' as another reason. Chaim Saiman, 'Restitution and the Production of Legal Doctrine' (2008) 65 Wash \& Lee L Rev 993 at 1006; and similarly, Langbein 
answer would convince only if for some reason restitution law somehow resisted non-doctrinal scholarship. Langbein actually comes close to suggesting this when he says that " $[\mathrm{t}]$ he study of restitution requires an environment that treats doctrine with respect.9 ${ }^{.9}$ Langbein does not explain why restitution is different from other areas of law, but on its face this claim seems odd. Hanoch Dagan's self-consciously realist and largely Americanorientated work on restitution illustrates this does not have to be the case. ${ }^{10}$ Langbein may have meant that by this statement that theoretical work on law can only emerge against a background of developed doctrine. I have my doubts about this view in general, as there are many examples of theoretical work on law that is developed directly against doctrine, or to fill gaps in doctrine, or is written with indifference to (or ignorance of) it. At any rate, in the case of unjust enrichment, the doctrinal foundation was there. As Langbein himself says, it was Americans who were the first in the common law world to start thinking about unjust enrichment in a doctrinally systematic way, and thanks to the efforts of a small group of scholars the Restatement (Third) of Restitution and Unjust Enrichment has just been published. ${ }^{11}$ All along, drafts and discussions for this and the previous (unfinished) Restatement were published. These could have been grist to an

talks about the 'marginalisation of private law,' in Langbein, supra note 3 at 61. But, once again, it is not difficult to find articles on contract, tort, bankruptcy, securities regulation, corporate finance and other areas of private or commercial law in the leading American journals.

${ }^{9}$ Ibid at 62.

${ }^{10}$ See Hanoch Dagan, The Law and Ethics of Restitution (New York: Cambridge University Press, 2004) [Dagan, Restitution]; Hanoch Dagan, 'Restitution's Realism' in Philosophical Foundations, supra note 5 at 54. Dagan is not alone. Though small in comparison to other branches of private law there has been other non-doctrinal work on restitution by American scholars such as Christopher Wonnell, 'Replacing the Unitary Principle of Unjust Enrichment' (1996) 45 Emory LJ 153; Saul Levmore, 'Explaining Restitution' (1985) 71 Va L Rev 65; Richard A Epstein, 'The Ubiquity of the Benefit Principle' (1994) 67 S Cal L Rev 1369. I explain this scholarship in note 90 and accompanying text below.

${ }^{11}$ See Restatement (Third) of Restitution and Unjust Enrichment (2011). Now that it is there, we have been promised a 'restitution revival.' See Caprice L. Roberts, 'The Restitution Revival and the Ghosts of Equity' (2011) 68 Wash \& Lee L Rev 1027 at 1027, but it turns out that this revival is, for the time being, only an expectation. See ibid at 1041. 
aspiring scholar's mill, and yet most American lawyers remained uninterested.

Saiman attempted to explain this divide by telling us that 'the amount of restitution law produced by a given [legal] system corresponds to the degree that restitutionary remedies are conceptualized as correlating to specific legal entitlements arising from property and contract. Hence, the less remedial discretion allotted to the courts, the greater the need for substantive law of restitution. ${ }^{, 12}$ But this is like saying that the more restitution law is perceived to be needed, the more of it will get produced. The question remains: why do different legal systems have different perceived needs for such developments? And for that matter, why are American lawyers less troubled by remedial discretion?

It is these questions that this essay seeks to address. The answer I propose for this puzzle has to do with the role unjust enrichment played in English and Commonwealth law. I will argue that, for various reasons that will be explained below, American academic lawyers had no need for unjust enrichment; to English lawyers, by contrast, restitution law provided a solution to otherwise intractable problems. To understand why this was the case we need to look into a matter that seems to bear no relationship to the question at hand, namely the way American law and English law conceive of the relationship between law and politics. I argue that this difference leads to distinct ways of understanding the shape and limits of acceptable doctrinal innovation in the two legal systems. It is these differences, I will argue, that provide a more satisfying explanation for the trajectories restitution law and restitution scholarship took in these two countries.

If I am right about this, then this claim has broader significance than the rather narrow point from which it emerges. In the familiar distinctions of legal traditions American law is often classified with the rest of the law of the English-speaking former British colonies as belonging to the 'common law' family. In some respects this classification is, of course, unobjectionable. But it is no secret that in some respects American law has taken a different path from the rest of the common law. Especially in the area of private law, Commonwealth lawyers, both academic and practicing, seem to implicitly accept this parting of ways by showing less interest in American court decisions, which (despite their much larger number) are much less frequently cited or analyzed in Commonwealth textbooks than the decisions from other Commonwealth jurisdictions; American legal scholarship in these

\footnotetext{
${ }^{12}$ Saiman, supra note 8 at 1039-40.
} 
areas is also, with a few exceptions, largely ignored. The essay seeks to provide part of an answer as to why. Interestingly, what emerges from it is that at least in this area, the familiar common law/civil law divide (one that some English doctrinal scholars rely on in seeking to restrict the influence or borrowings from other European legal systems) is misleading. In some important respects, English law is now much closer to European civil law than to American law.

One caveat: my account attempts to explain the different fates of restitution in English and American law as, in part, resulting from different fundamental perceptions of the relationship between law and politics. These differences are most visible from a certain distance; move closer and all patterns disappear, move away and differences vanish. No doubt one could find representatives of what I describe as the typical English approach on the American side, and vice versa; in fact, later in this essay I extend my explanation to account for some of the debates among English restitution lawyers. Nevertheless, I believe that the patterns I describe reflect are real, and that they are crucial for understanding the different fates of restitution in the two countries.

Here is how my argument will unfold. I start with briefly presenting a sketch of the significance of ideas to legal thought, and will explain how this perspective helps in understanding the sort of explanation I will be offering here. In section II I explain the problem that restitution was meant to solve in English law. I argue that restitution was the means for solving existing problems that doctrine within other areas of law proved incapable of solving. This answer, however, raises an immediate question: why was there a need to develop these solutions outside these particular areas of law, instead of correcting the problems in existing doctrine? Section III begins to answer this question by discussing an issue that looks at first far removed from doctrinal problems in private law, namely the way in which different legal systems conceptualize the relationship between law and politics. I argue there that certain ways of understanding this relationship constrain the sorts of answers available within English doctrine. In section IV I apply this distinction to the question and restitution and show how it explains the different fate of restitution in English and American law, both at the doctrinal level and in the work of scholars. 


\section{The Power of Ideas}

The familiar version of the modern history of unjust enrichment in English law has the individual efforts of Robert Goff and Gareth Jones, of Peter Birks, and perhaps a few others scholars, as major turning points in changing an area of law that many doubted even existed into the most active area for new doctrinal scholarship. In this story, had it not been for the perseverance of these authors, English restitution law might have looked quite different today, as powerful voices were opposed to the addition of restitution (or unjust enrichment) to the list of recognized legal categories. Though in part true (and significant), this account is in many respects an example of the fallacy of post hoc, ergo propter hoc. We know what happened, and so we tell the story as though it was bound to happen. But compare this story to a different one: In the late 1970s a group of scholars tried to import the then emerging ideas of law and economics into English legal scholarship. These studies were published in all the leading English journals, but what turned into a flood in the U.S. has had virtually no impact on English law. Had economic analysis caught on in Britain, no doubt these articles would have been hailed now as early precursors of what became a major development. As there was no such development, there is no story to tell. The very different fates of restitution and economic analysis show that we need to look elsewhere for the missing ingredient in our story, the one that explains why certain ideas have impact while others do not.

The same question arises closer to our subject: had restitution been a success in the United States, William Keener, the author of the first Englishlanguage treatise on the subject, and even more so Austin Scott and Warren Seavey, the reporters of the 1937 Restatement of Restitution, would have been considered visionary path-breakers, minor heroes in the pantheon of American law. But as restitution languished at the dark corners of American law and their work was neglected, the names of Keener, Scott and Seavey have been forgotten. They are now familiar only to the small coterie of scholars who keep the feeble flame of American restitution law alive. It is not enough, then, to show that new ideas started with someone. They always do. The question is what makes certain ideas stick. The rest of the essay attempts to explain what that extra ingredient is in the context of restitution.

Before I turn to that question, I must preface my account with a short explanation of a more general kind. Legal systems are not just the sum of norms (rules, principles). A crucial element in understanding legal systems is 
what might be called the 'ideology' of the legal system. I use the term ideology in a non-pejorative sense, and it is not limited to (although it includes) the political orientation of the legal system to non-legal ideas: different legal systems can both be politically 'liberal' and yet have a very different ideology in other regards. Thus, ideology will include attitudes regarding the openness of the legal system, the role of courts and lawyers in the legal system, the relative weight a given legal system tends to give to certainty over other considerations, and so on. This ideology will affect foundational questions, such as the appropriate issues for the legal system to deal with and the appropriate ways of dealing with them, as well as more mundane issues like the appropriate methods for interpreting legal materials, the amount of deference that should be given to other branches of government and so on. ${ }^{13}$ This is why legal ideology is both powerful but easy to miss. As the ideology of a legal system is part of the background of all the law, it is easy to overlook how contingent it is and to treat local attitudes as part of the order of the world. And because in one way or another it affects all aspects of a legal system, it is often very difficult to change.

This has important implications for understanding the limits of legal change. It is because of the ideological component of legal systems that good norms from other legal systems often do not travel well between jurisdictions. Ignoring ideology, a lawmaker seeking to improve the laws of her jurisdiction could simply look for those norms best supported by reason, or to ideas coming from any existing or imaginary jurisdiction, and all will be equally good candidates for importation. In reality, this is not often the case. New legal ideas have staying power to the extent that they can be made to fit within the existing ideology of a legal system. What this means is that they will be treated as valuable when they are perceived to offer adequate solutions to (what are taken to be) open problems. Ideas that satisfy only one of these two conditions are likely to be considered (at best) interesting for 'academic' discussion but irrelevant in practice.

Once a solution is incorporated in a legal system, it becomes part of the background against which new ideas and new solutions to other problems are assessed. Because new ideas are incorporated to the extent that they fit the existing legal ideology, quite often legal change will operate through a kind of feedback loop mechanism that tends to deepen the ideological path to which a legal system is already committed. It is through this mechanism that initial

${ }^{13}$ C.f. Anthony Ogus, "The Economic Basis of Legal Culture: Networks and Monopolization’ (2002) 22 Oxford J Legal Stud 419 at 421-23. 
small differences between legal systems can become more pronounced with time until at a certain point meaningful exchange of ideas between the legal systems becomes difficult. ${ }^{14}$ Just as the geographical separation of two groups belonging to a single species can lead to speciation, the separation of legal systems can lead to legal system speciation. Because the reshaping and changing of legal systems happens through conscious efforts rather than random change, reversing course is easier in the domain of legal ideas than in the biological world, but it is noteworthy that when such efforts at reversing courses are made, the change is often accompanied by efforts to expose, or invent (the two are not always easily distinguished), a shared origin. ${ }^{15}$

In what follows I will try to demonstrate that it is the ideology of English and American law, and in particular their fundamental, and fundamentally different, attitudes to the relationship between law and politics, that explain the different fates of restitution law in these countries.

\section{Unjust Enrichment as the Solution to the Problem of Unjust Doctrine}

Since much of the Commonwealth doctrinal scholarship on unjust enrichment has been in one way or another a development of, or a reaction to, the work of Peter Birks it would be helpful to start with him. Birks was the first to admit that many of his most fundamental ideas about law in general and restitution law in particular were derived from Roman law. What made his ideas so influential, however, was that he did not develop these ideas within the niche area of Roman law scholarship. Rather, for the most part he translated them to concepts that made them comprehensible to the English common lawyer. He argued that these ideas could provide doctrinally

\footnotetext{
${ }^{14}$ More precisely, when ideological differences between legal systems are initially small, unequal access to new ideas which reinforce the existing differences can result in the legal systems drifting away from each other. Geography, language, and political ties have traditionally been the source of unequal access to new ideas. Globalization and technology may overcome some of these barriers, but not necessarily others. At the same time, they may exacerbate the problem of information glut that often leads to discrimination in favour of more local or more similar ideas. There is, of course, much more to be said about these issues.

15 In the European context see Reinhard Zimmermann, Roman Law, Contemporary Law, European Law: The Civilian Tradition Today (Oxford: Oxford University Press, 2001) at 107-14.
} 
respectable solutions to existing legal problems in English law. Though he never wrote a treatise on restitution, his work followed a path that was familiar to contemporary English private lawyers: it was based on 'look[ing] downwards to the cases, ${ }^{, 16}$ and was conceived as a non-political investigation into 'lawyers' law.'

These methodological commitments led to two substantive principles that were at the heart of Birks's thinking on unjust enrichment. The first was that unjust enrichment is a member in full standing of the law obligations alongside contract and tort. By this what Birks meant was not merely that unjust enrichment law was a useful way of organizing material for pedagogical or explanatory purposes, but that unjust enrichment represented a fundamental legal category, one that corresponded to the real divisions of the law. ${ }^{17}$ The second commitment was that unjust enrichment, despite its name, has relatively little to do with justice. Birks could not have put this point more strongly than he did: with almost no loss of meaning, Birks tells us, 'unjust enrichment' could be called 'pink enrichment.' ${ }^{, 18}$

I wish to present a picture that challenges both points. I believe there are no true legal categories over and above the categories we create. The way courts classify cases may, for certain purposes, be a useful way of classifying them. But in other instances different classifications can be more useful. There is nothing wrong with classifying the topic of vitiated contracts within contract law, or that of gain-based remedies for wrongs under tort law; there

${ }^{16}$ Peter Birks, An Introduction to the Law of Restitution, paperback ed (Oxford: Clarendon Press, 1989) at 23; see also ibid at 99.

${ }^{17}$ See generally Peter Birks, 'Property and Unjust Enrichment: Categorical Truths' [1997] NZ L Rev 623; see also Nicholas J McBride, 'The Classification of Obligations and Legal Education' in Peter Birks, ed, The Classification of Obligations (Oxford: Clarendon Press, 1997) 71; McInnes, supra note 5 at 101, 114 (complaining about the principles of the law of restitution being 'manipulated' or 'abused'). Saiman also seems to hold the same view when he complains that "[1]acking a formalized "law of restitution" cases of mistaken payment were analyzed 'through the eyes of tort and contract.' Chaim Saiman, 'Restating Restitution: A Case of Contemporary Common Law Conceptualism’ (2007) 52 Vill L Rev 487 at 524. But this is a mistake only if one believes that legal categories reflect some real, conceptual truths.

${ }^{18}$ See Peter Birks, Unjust Enrichment, 2nd ed (Oxford: Clarendon Press, 2005) at 274-75; Birks, supra note 16 at 19-23. Others expressed similar views. See Andrew Burrows, The Law of Restitution, 3rd ed (Oxford: Oxford University Press, 2011) at 4, 86-87; McInnes, supra note 5. 
is also nothing wrong with classifying them for different purposes as part of the law of restitution. Legal scholars do not discover categories that are true, but rather articulate categories that are useful. Of course some categories may be more useful than others, but even here, the useful classifications for a lawyer representing a hospital may be very different from those useful for a university lecturer. ${ }^{19}$

The second point is that contrary to the view that unjust enrichment has little to do with justice, I contend that a main reason why restitution law flourished in English law is because it provided a doctrinally respectable way of avoiding what were perceived to be unjust results in other areas of law. It is for this reason that restitution law looks so much like the result of a looting campaign in other legal categories: a bit from contract, a chunk from tort, something from property with a dash of equity. A couple of examples will help substantiate this point. Consider, first, the simple, 'core case' of unjust enrichment, mistaken payment. ${ }^{20}$ Why does this case require legal intervention? The answer must include two elements. The first is that the outcome where the recipient retains the money is deemed 'wrong.' By wrong I do not mean, of course, legally wrong; I mean a situation that is in some inarticulate sense morally problematic. Now, there can be all kinds of elaborate theories-having to do with autonomy, self-determination, economic efficiency, fairness - to explain why such a situation in which the payee retains the mistaken payment is 'wrong,' and these different explanations may lead to real differences in certain contexts, but Birks presents this case as an axiom, one that requires no explanation and cannot be questioned.

Assume he is right in treating this is a core case. The question for the lawyer then is how the law should deal with these kinds of situation. Unjust enrichment scholars have argued that the doctrine of unjust enrichment is necessary for handling such cases, but it is not immediately clear why. It is obvious that ownership is not always matched by possession, and that there is nothing wrong with that: books could not be lent and houses could not be rented if that were not the case. But such separation of ownership from

${ }^{19}$ It may be due to humans' internal wiring certain legal divisions will appear to most or even all humans as more 'natural.' Showing this, however, will require appeal to pre-legal psychological categories, not to the 'internal' coherence of certain legal categories.

${ }^{20}$ The designation of this as the core case of unjust enrichment is in Birks, supra note 18 at 6-7. 
possession usually requires a voluntary act on part of the owner; when such a voluntary act is not present, then (typically) the owner has a claim for retaining possession quite simply as one of the "incidents of ownership. ${ }^{21}$ The basic idea invoked here-'This is mine! Give it back to me'-is so simple that toddlers begin to grasp it when they are about fourteen months old. ${ }^{22}$ Therefore, a possible way of handing cases of mislaid, forgotten, and mistakenly-given property is by appealing to this simple idea, something that even the most enthusiastic supporters of unjust enrichment admit. ${ }^{23}$

Why then is unjust enrichment invoked in the case of mistaken payment? The reason is certain complications introduced by the law: there are situations in which title passes despite the fact that the conditions we commonly think of as the reasons for the transfer of property (e.g., voluntary action) have not been met. This mismatch between our intuitive ideas of property and the requirements of property law is deemed by us to be unjust, not (merely) in the legal sense of invoking a restitutionary claim, but in the everyday meaning of the term: it is considered morally problematic, it is considered 'wrong.' For whatever reason, many people think that absentmindedness should not normally suffice for losing one's property regardless of niceties about legal title. When this point is recognized, it is natural to go back to the very same proprietary ideas that were relied upon before. What explains the doctrine here, what distinguishes cases in which

${ }^{21}$ See Tony Honoré, 'Ownership' in Making Law Bind: Essays Legal and Philosophical (Oxford: Oxford University Press, 1987) 161 at 167 ('The owner ... has characteristically a battery of remedies in order to obtain, keep, and if necessary get back the thing owed [to him],' which include 'the claim for specific restitution of goods, and the vindication').

${ }^{22}$ See Maris Monitz Rodgon \& Sue E Rashman, 'Expression of Owner-Owned Relationships among Holophrastic 14- to 32-Month-Old Children' (1976) 47 Child Dev 1219; c.f. OW Holmes, 'The Path of the Law' (1897) 10 Harv L Rev 457 at 477 ('Sir Henry Maine has made it fashionable to connect the archaic notion of property with prescription. But the connection is further back than the first recorded history. It is the nature of man's mind.').

${ }^{23}$ See Lionel Smith, 'Unjust Enrichment, Property, and the Structure of Trusts' (2000) 116 Law Q Rev 412 at 422-23 (although oddly he relies on Occam's razor to conclude that such claims should be treated as unjust enrichment claim); Graham Virgo, The Principles of the Law of Restitution, 2nd ed (Oxford: Oxford University, 2006) at 570. Even those wishing to give a more minimal place to property-based claims, give them room in these cases: Birks, supra note 18 at 64; Birks, supra note 16 at 50-51; Burrows, supra note 18 at 169. 
the payment should be returned from cases (such as those involving gifts) in which it should not, has to do with our underlying ideas of property. In the case of a mistaken payment there was no conscious, willed decision to give the money to another; in the case of a cash gift, there was. And so even in these cases, "where unjust enrichment is most needed, ${ }^{24}$ it turns out that unjust enrichment does not explain the law's treatment of mistaken payment. If asked to describe this situation we would say 'the money in question did not really belong to the payee, and therefore if she retained it should be unjustly enriched,' not the other way around.

My other example is briefer and more specific. It is the problem known as battle of the forms. In such a case what typically happens is that two parties try to contract by exchanging their standard form contracts. One party sends its own form, to which the other replies with its form. Performance then begins without the second form being formally accepted. The problem arises when the latter form is different in some important elements from the first one. Traditional offer-and-acceptance analysis classifies the second form as a rejection of the original offer and a new counteroffer that was never accepted. In most cases matters proceed without a hitch, but, obviously, sometimes they do not. What is to be done in such cases? When a case like this reached the English Court of Appeal the bold spirit of Lord Denning had no difficulty in asserting that the "traditional analysis ... is out of date, ${ }^{25}$ and he had no qualms about departing from it. The other judges agreed with him on the result, but they sought to do so by maintaining the traditional rules. What is interesting and important for the argument I will develop below is that in England there was academic support for the view that the right way to solve this problem is by appeal to restitution. ${ }^{26}$ Though the issue is different, the structure of the argument is

${ }^{24}$ Lionel Smith, 'Restitution: The Heart of Corrective Justice' (2001) 79 Tex L Rev 2115 at 2141 n 106.

${ }^{25}$ Butler Machine Tool Co. Ltd. v Ex-cell-O Corporation (England) Ltd (1977), [1979] l WLR 401 at 404 (CA).

${ }^{26}$ See Ewan McKendrick, 'The Battle of the Forms and the Law of Restitution' (1988) 8 Oxford J Legal Stud 197; Birks, supra note 16 at 466-67, crisply exemplifies the argument I will develop below: 'If the courts abandoned the attempt to discover a contract by rigidly applying, or distorting, the rules of offer and acceptance and instead concluded that there was no contract ... transfers made under the abortive contract could ... be handled through non-contractual (restitutionary) request and acceptance.' 
the same: we have a legal doctrine that leads to what is perceived as a problematic result, and unjust enrichment is invoked to solve the problem.

Limits of space preclude me from offering other examples, but I believe that for virtually every case in which unjust enrichment has been invoked as justification, a similar story could be told: a problem with a doctrine in some area of law, and appeal to the 'principle against unjust enrichment' to solve it. $^{27}$

\section{The Political Foundations of Doctrinal Scholarship}

The last section considered some of the cases that doctrinal lawyers say belong to the law of unjust enrichment in order to show that the doctrine was used to circumvent unjust results created by other doctrines. This claim, however, raises an immediate problem: if this is indeed the case, why was there a need for invoking unjust enrichment? It would have been easier to simply change the existing problematic doctrine instead of adding a further doctrinal layer in the shape of restitution law. Why have scholars opted for complex and circuitous solutions based on the vague idea of unjust enrichment when easier routes were available? The doctrinal answer offered to such a challenge is that it is trite law that in a situation like this property

${ }^{27}$ Though they do not always present it in this way, one can see this by reading the work of unjust enrichment skeptics. See e.g., Peter Jaffey, The Nature and Scope of Restitution: Vitiated Transfers, Imputed Contracts, and Disgorgement (Oxford: Hart, 2000); Steve Hedley, A Critical Introduction to Restitution (London: Butterworths, 2001); Joachim Dietrich, Restitution: A New Perspective (Leichhardt: Federation Press, 1998). This does not cover all the cases that appear now in books on 'restitution,' but the remaining cases (such as those dealing with vitiated contracts) are cases of redrawing of boundaries between different areas of law. Here the restitutionary analysis is superfluous: the only reason why it could be unjust not to return what one received as a result of a vitiated contract is some other rule (one presumably having to do with property) that would explain why it is wrong to retain whatever one received. It is then failing to comply with that rule that implies unjust enrichment. But if that is the case, then unjust enrichment simply piggybacks on that other rule. 
passes to the payee. ${ }^{28}$ But this does not explain why restitution is needed: all law, even trite law, can be changed. ${ }^{29}$

I have already described in general terms what I take the right answer to be: the solutions adopted had to be perceived as adequate solution to an open problem, and for reasons that I will try to explain below unjust enrichment appeared an adequate solution whereas changing existing legal doctrine did not. This at first may seem odd. If there is something that common lawyers pride themselves (and their legal tradition) on, it is their pragmatism and flexibility, and their dislike for excessive ('German') conceptualism. ${ }^{30}$ Against this background the rigid attitude suggested here may appear at first quite surprising. What could explain it?

There is what might be called the 'sinister' answer, offered by Jeremy Bentham and reiterated later by many others: lawyers adopt complex rules because it is in their interest to make sure that their services are needed. I have no doubt that there are cases to which Bentham's idea is applicable, but I think this case is not one of them, not least because the concern with restitution has, at least until recently, largely been an academic affair which actually had little impact on legal practice. ${ }^{31}$ Furthermore, this argument cannot explain the difference between English and American law on the matter. Therefore, I wish to suggest a different explanation, and that is that a different understanding of the relationship between law and politics in these two legal systems has led to very different views on the limits on acceptable legal change. More specifically, my argument will be that in some important sense the simple solutions offered above are unavailable to English lawyers, because they would be considered in some sense political, and as such not legal and therefore inadequate. This view depends on a particular understanding of the relationship between law and politics, one according to which the two domains are largely separate and therefore some possible solutions to legal problems are not solutions that lawyers can properly

${ }^{28}$ Burrows, supra note 18 at 30 . This point is equally applicable to mistaken payment.

${ }^{29}$ This is effectively the answer given by, for example, Charlie Webb, 'Property, Unjust Enrichment and Defective Transfers' in Philosophical Foundations, supra note 5 at 335, 355-58.

${ }^{30}$ See generally PS Atiyah, Pragmatism and Theory in English Law (London: Stevens and Sons, 1987).

${ }^{31}$ At least if we are to believe Hugh Collins, 'Legal Classifications as the Products of Knowledge Systems', in The Classification of Obligations, supra note 17 at 57, 68 . 
suggest. By contrast, in the United States, where the prevailing view on the relationship between law and politics is fundamentally different, there was no similar barrier to adopting the simpler solutions.

\section{(a) Two Views on the Relationship between Law and Politics}

My central argument is that English law and American law have a different ideology on the question of the relationship between law and politics. Now if by politics we mean questions concerning the distribution of resources in society, then few will doubt that law, even private law, is in some sense tied to politics. In another sense, there seems to be general agreement that all law, including public law, is separate from politics. All judges, for example, insist that in deciding cases, they are following the law, not their personal political opinions; and all agree that in some sense law is undermined when it is infiltrated by politics.

And yet there is an intuitive sense in which American courts are touched by politics in a way that judges in the Commonwealth are not. Throughout American history courts have often been asked to decide on politically controversial questions (such as slavery, abortion, health care, same-sex marriage). There is also a burgeoning academic industry, frequently discussed also in the press, that analyzes court decisions according to the judges' perceived political orientation. In the Commonwealth, to varying degrees, the courts do not play that role, and it is much rarer to consider judges' open in openly political terms.

This difference has its roots, in part, in the different political traditions of England (and through it the rest of the Commonwealth) and the U.S, and the relative role of law in political debates. ${ }^{32}$ One of the most distinctive marks of American law and scholarship of the last century has been attempts to spell out ways by which American courts could somehow be able to police and limit political discourse without entering into the forbidden territory of politics. Various 'theories' of judicial review were concerned with demarcating a proper role for courts when deciding on politically controversial cases. The search for 'neutral principles,' the distinction

32 The American story is in fact more complicated, as the courts were relatively uninvolved in political matters during the nineteenth century. See Mark Graber, 'Resolving Political Questions into Judicial Questions: Tocqueville's thesis Revisited' (2004) 21 Const Comm 485; see also note 54 below. The major change has taken place with the emergence of the regulatory state that was marked by attempts of the courts to make sure the government does not exceed its given powers. 
between principles and policies, the limitation of judicial review to infringements on the right to participate in the democratic process are all examples of this attempt. Similarly, the emergence of distinct 'theories' of statutory and constitutional interpretation were to a large extent a response to the need to keep law outside politics while dealing with and deciding on politically controversial matters. ${ }^{33}$ The hallmark of the American approachregardless of the very different solution proposed-has been the attempt to develop doctrinal and institutional tools for allowing courts some engagement with political discourse without getting embroiled in political debates.

It is no coincidence that all these debates have had, especially until recent years, very little resonance in the rest of the common law world. The simple reason is that there was no need for them, because the English (and Commonwealth) approach to the challenge of politics has been quite different. The prevailing view here has been that law is the antithesis of politics, and therefore maintaining the distinction between law and politics requires identifying the two distinct domains of law and politics and keeping them, as much as possible, separate. ${ }^{34}$ Dicey's influential interpretation of

33 This, for instance is a justification given for turning to originalism. See Antonin Scalia, 'Originalism: The Lesser Evil' (1989) 57 U Cin L Rev 849 at 854, $863-64$.

${ }^{34}$ See e.g. Birks, supra note 5 at 21 ('[Law] can perhaps never be perfectly autonomous. That is, it can never be perfectly detached from the judge's own perception of right and wrong. But it must be as autonomous as it can be made'); c.f. Burrows, supra note 18 at 4 (asserting he is concerned with 'what the law regards as unjust enrichment' and not what 'any one individual or commentator may think is unjust enrichment'). Notice that the attitude expressed here is that the alternative to law is personal opinion. This approach thus is exactly at odds with the efforts of many American scholars to distinguish 'ordinary' politics (which courts should not engage in) from an elevated form of politics that is the right domain of courts. See Dan Priel, 'Is There One Right Answer to the Question of the Nature of Law?' in WJ Waluchow \& Stefan Sciaraffa, eds, The Philosophical Foundations of the Nature of Law (Oxford: Oxford University Press, 2012) 322 at 331-34.

One of the best known proponents of this view has been Ronald Dworkin. It is for this reason that it is, I think, a mistake to suggest, as Duncan Sheehan does in 'Implied Contract and the Taxonomy of Unjust Enrichment', in Paula Giliker, ed, Re-Examining Contract and Unjust Enrichment: Anglo-Canadian Perspectives (Leiden: Martinus Nijhoff, 2007) 185 at 192-95, 211-12, that Birks's project is 'Dworkinian.' It is true that Birks presented his views on restitution as an interpretation of existing law, a view that superficial similarity to Dworkin's claim 
Parliamentary supremacy has been taken to mean that beyond relatively undemanding tests of legal warrant, courts did not interfere with political decisions. Instead of devising complicated means for distinguishing permissible from impermissible engagements with politics, the mainstream view has been that the only approach that maintains democratic values and that guarantees the legitimacy of courts, is that they altogether avoid politically controversial questions.

A further means for keeping law separate from politics has been an invigorated distinction between private law and public law. This distinction was not traditionally central to the common law. Indeed, the belief that there was no such distinction in English law was at one point considered a central distinction between the common law and civil law traditions (as well as a barely concealed basis for pride in the superiority of the common law).$^{35}$ But in recent years, perhaps as a result of a sense that politics was increasingly intertwined in public law, the divide between public law and private law has emerged as a fundamental category of Commonwealth common law. Part of the motivation for separating private law from public law has been the view that private law is, necessarily, non-political. ${ }^{36}$ On this view law, or at least

that answers to new legal questions must be found from within law. This, however, is not a distinctly Dworkinian idea, but rather one that has a long history in the common law. See Alan Cromartie, 'The Idea of Common Law as Custom' in Amanda Perreau-Saussine \& James Bernard Murphy, eds, The Nature of Customary Law: Legal, Historical and Philosophical Perspectives (Cambridge: Cambridge University Press, 2007) 203. Dworkin's novelty lies in his attempt to reconcile this traditional view of the common law with the view that ' $[1]$ aw ... is deeply and thoroughly political.' Ronald Dworkin, A Matter of Principle (Cambridge, Mass: Harvard University Press, 1985) at 146 By contrast, Birks's project is premised on exactly the opposite view, that finding the solution to open legal problems within the law is essential for keeping law and politics separate. See Peter Birks, "Equity in the Modern Law: An Exercise in Taxonomy' (1996) 26 UW Austl L Rev 1 at 97-99.

${ }^{35}$ See JWF Allison, A Continental Distinction in the Common Law: A Historical and Comparative Perspective on English Public Law (Oxford: Oxford University Press, 1996) at 1 ('until this century, the distinction [between private and public law] was little known in England'); c.f. AV Dicey, Lectures Introductory to the Study of the Constitution (London: Macmillan, 1885) at 177-79, 199-202 (arguing that one of the meanings of the English rule of law is that all claims of individuals against the government must be framed as ordinary common law claims).

${ }^{36}$ See e.g. Birks, supra note 34 at 97-99 (arguing that development of private law should be given to 'legal experts' in order to prevent the 'politicisation' of the law and 'the realist destruction of legal science'); Andrew Burrows, Understanding the 
private law, is corrupted when its rules are subjected to politics. ${ }^{37}$ A clinically clean statement of this view is found in Ernest Weinrib's provocative suggestion that 'the purpose of private law is simply to be private law. ${ }^{38}$

To a lawyer seriously committed to this view, these words are not just a slogan. One of their practical implications is that they impose a limit on the permissible sources the lawyer should consult in her work. It is not simply that looking at the work of economists or philosophers is unnecessary for understanding and developing the law; for a proponent of this view, in an important sense it is wrong to do, for it is within the law that one need and should look for determining the content of legal change and it is legal materials that determine its acceptable limits. Another important aspect of this view is that private law is the domain of expert lawyers and should largely be left outside democratic decision-making. It should not be legislated (for proponents of this view, the epitome of politics), ${ }^{39}$ and to the extent that it is legislatively changed, the change should be the result of work from a non-political (and doctrinal-lawyer-dominated) Law Commission. ${ }^{40}$

The most important practical implication of this view for our purposes is that legal change is considered a different kind of beast from political change

Law of Obligations: Essays on Contract, Tort and Restitution (Oxford: Hart, 1998) at 122 ('To my way of thinking, for the common law to react according to the political fad of the moment would be to contradict its very essence; contract, tort and restitution rest on fundamental long-term values that, while evolving and adapting to new conditions over the course of time, and while influenced by long-term policies, should be immune from short-term party politics.'). What Burrows calls 'political fad' others call democracy.

${ }^{37}$ The intellectual background for this group was provided in the very influential work (in these circles) of Weinrib. See, for example, Ernest J Weinrib, The Idea of Private Law (Cambridge: Harvard University Press, 1995), where many of these themes are discussed.

${ }^{38}$ Ibid at 21; accord Robert Stevens, Torts and Rights (Oxford: Oxford University Press, 2007) at 326 ('it is meaningless to talk of the law of torts having a function or goal at all'). Not surprisingly, both scholars explicitly insist that law (or at least private law) is autonomous from politics. See Weinrib, supra note 37 at 210-14; Robert Stevens, 'Torts' in Louis Blom-Cooper et al, eds, The Judicial House of Lords 1876-2009 (Oxford: Oxford University Press, 2009) 629 at 651-52.

${ }^{39}$ As Lord Radcliffe put it '[1] awyers tend to regard statute law as not quite the equivalent of real law.' Viscount Radcliffe, 'The Place of Law Courts in Society' in Not in Feather Beds: Some Collected Papers (London: Hamish Hamilton, 1968) 27 at 30.

\footnotetext{
${ }^{40}$ Burrows, supra note 36 at 136, 166.
} 
of the law. Whereas the latter is (especially within the British system) in principle still largely unconstrained by law, the former is governed by rules on what count as 'permissible' moves. To use a word much favoured by proponents of the former view, legal change must have a certain form. These impose some limits on the outcomes one can reach, but they also impose less-discussed limits on the way to get to them.

This does not yet explain the difference between legal and political change. Isn't it obvious that change in the law must be grounded in some normative idea, and as such must be grounded in political arguments? To proponents of the model of law and politics discussed here the answer is 'no': to maintain the idea of law as an autonomous discipline it must be that legal change-one based on the law's own 'self-understanding,' on its own resources-be different from change based on any other discipline. One of the most familiar ways in which this idea is articulated is in the distinction courts always make between the kind of changes in the law they can bring about and the change that can only be brought about by the legislature. It is often thought that such explanations are based on the worry that the courts will overstep into the legitimate domain of an elected Parliament, that is, that they will violate democratic legitimacy. And though this is true, quite often the focus of the explanation is subtly but importantly different: such unacceptable change is problematic because it requires stepping outside the legitimate powers of courts. These are not two sides of the same coin. It is not simply that the power of legal change by the courts ends where that of the legislature begins; on this view there are independent considerations, having to do with the nature of (private) law, that limit courts' permissible action that have little to do with democracy.

The fundamental difference between the two has to do with the difference between acts of will and arguments of reason. ${ }^{41}$ Political changebecause it derives its authority from democratic principles-is the domain of acts of will; by contrast, legal change-because its authority can come on this view only from within the law itself-is acceptable only if it comes from a reinterpretation of legal materials. As such, on this view legal change is acceptable only if in some sense it does not change the law at all. A politician seeking to change the law can simply declare: 'the law will be better if we change it in this way.' Odd as it may sound, from the perspective considered here this simple and seemingly obvious line of argument is not available to

${ }^{41}$ See MJ Detmold, 'Law as Practical Reason' (1989) 48 Cambridge LJ 436 at 437-55 for an instructive discussion. 
the lawyer, because what counts as 'better' is a political question, something on which people of different political persuasions will hold different views. This is why the lawyer must resort to a different kind of argument, one compelled by the legal materials themselves. Even when reaching the same outcome (and for that matter, even if the lawyer happens to share the view with the politician that the outcome would be 'better'), this can never be a reason for the decision.

In theory at least the difference between the two approaches is vast, ${ }^{42}$ and it explains some fundamental aspects of doctrinal legal practice. This, for example, is the foundation of the old idea-to which one finds support among doctrinal lawyers even today-that judges and lawyers never change the law, only discover it. ${ }^{43}$ Even when not adopting such a view, the idea of abolishing a doctrine is treated with suspicion, for in some sense it is not an acceptable move in the 'game,' it suggests a kind of breakdown of the rules. It is perhaps for this reason that the most natural (perhaps the only available) route for doing that is by arguing that the decision being overruled was 'wrongly decided' in the sense that it could not have been reached on any reasonable interpretation of existing legal materials at the time it was handed down. ${ }^{44}$ Doing that makes it possible to 'return' the law from the wrong path it has taken to the true course it should always have taken, thereby seemingly not changing the law.

I need less space to describe the mainstream view among American lawyers, because it is quite simply more-or-less the opposite. The starting point for debate among American lawyers is that in an important sense law is part of politics. Law is a means for achieving political ends, law can be used

${ }^{42}$ Whether the difference is significant in reality is another matter. Against my distinction between legal and political change mentioned in the text, we can rephrase the familiar critique of formalism as the claim that in reality the difference between legal and political change is small, because legal materials are loose enough, so it is possible to construct a legally credible argument for a wide range of different outcomes.

${ }^{43}$ See Peter Birks, 'Mistakes of Law' (2000) 53 Curr Legal Probs 205 at 217-18, where Birks states that while judges are permitted to bring about interpretative change, they cannot abolish existing rules in the way legislature do. Birks says this long after the Practice Statement (Judicial Precedent), [1966] l WLR 1234, that allowed the House of Lords to depart from its earlier decisions. For an interesting discussion see Detmold, supra note 41 at 440-4l.

${ }^{44}$ See e.g. Murphy v Brentwood District Council (1990), [1991] l AC 398 at 471, HL (Eng); c.f. R $v$ R (1991), [1992] l AC 599 at 612, HL (Eng). 
to pursue political ends, and legal institutions are forum of political debate. This is clearly the case in contentious, highly visible constitutional cases, but it is also the case in 'private' law cases. It reflects a philosophy that rejects the divide between reason and will and conceives all of it as having its source in the will of the lawmakers. ${ }^{45}$ Underneath this rather abstract idea one finds a whole range of different views running the gamut from the view that law is politics with an odd jargon to the view that law is a kind of idealized politics. But the view that law is separate or autonomous from politics is, for the most part, treated as not just wrong, but naïve and even dangerous.

Because law in the U.S. is understood in more overtly political terms, legal change, including the abolition of existing doctrines, is easier to explain in more direct terms: if the law no longer serves whatever goal is set for it, it should be changed. Of course, even within this approach courts operate under various constraints, and judges do not simply decide cases any way they want. The difference is, however, that within this approach the limits of legal argument and legal change are thought to be determined on the basis of political or institutional analysis, not on the basis of a fixed conceptual division between law and politics. True, even in American law there are those who call for greater 'formalism' (for our purposes, greater separation between law and politics) but unlike the conceptual approach, these calls typically invoke explicitly political or institutional arguments in support of their position. ${ }^{46}$

\footnotetext{
${ }^{45}$ A clear rejection of the divide between reason and will, which reflects the very different understanding of the divide between law and politics, is found in Erie Railroad Co v Tompkins, (1938) 304 US 64 at 79, endorsing Black \& White Cab v Black \& Yellow Cab, (1928) 276 US 518 at 532-34 (Holmes J., dissenting). There is a corresponding distinction between the two views with regard to the role they assume law plays in practical reasoning. On one view law is there to free people from the need to engage directly with moral and political considerations; on the other view, law's role in practical reasoning is to engage people in moral and political questions. The idea of law operates through exclusionary reasons is thus not a conceptual truth about law but a reflection of a particular political theory. See Dan Priel, "Are Jurisprudential Debates Conceptual? Some Evidence from Democratic Theory, (2012) 50 Osgoode Hall LJ.

${ }^{46}$ See e.g., Frederick Schauer, 'Formalism' (1988) 97 Yale LJ 509 at 538-44; Cass R Sunstein, 'Must Formalism Be Defended Empirically?' (1999) 66 U. Chi L Rev 636 at 641 ('With some qualifications, my answer is "Yes.").
} 


\section{(b) An Illustration: The Universality of the Common Law}

When the fundamental difference in English and American law's conceptualization of the relationship between law and politics is brought to light many of the differences between the two legal systems become clearer. Some of the differences, such as English courts' greater reluctance to enter into issues that are politically contested, are in plain view; ${ }^{47}$ some, like English courts' greater adherence to precedent, go slightly deeper. ${ }^{48}$ Some go deeper still: the issues that preoccupy legal debates, the very different style of legal scholarship, the views regarding the relationship between the common law and statute law, even the dominant jurisprudential theories. The differences also have implications beyond the strict limits of legal doctrine; I believe, for example, that the different approaches to legal education in the two countries are, at least in part, explicable by this fundamental distinction. ${ }^{49}$

Here I wish to highlight a less familiar issue explained by the different attitude towards law and politics, namely the attitude toward the universality of the common law. This difference is particularly relevant in the context of restitution because much of the doctrinal work on unjust enrichment has been a joint effort of scholars from all over the Commonwealth. This is no coincidence. A fundamental idea that underlies, often quite explicitly, much of the work of doctrinal scholars is that the common law is some kind of single unified system, such that solutions reached in one legal system should be largely the same as those in others. ${ }^{50}$ This is not treated merely as a reflection of common historical origin, but as a fact of normative significance such that divergences between common law jurisdictions are thought to be a cause for concern in a way that, say, differences between English and French

${ }^{47}$ For a representative discussion of English judges' attitude see, for example, Patrick Devlin, The Judge (Oxford: Oxford University Press, 1978) at 6-7, where he assesses the U.S. Supreme Court's 1960s decisions and says that no English court would have agreed to decide the issues American courts have dealt with.

${ }^{48}$ See generally PS Atiyah \& Robert S Summers, Form and Substance in AngloAmerican Law: A Comparative Study of Legal Reasoning, Legal Theory, and Legal Institutions (Oxford: Clarendon Press, 1987) at 118-27.

${ }^{49}$ See generally ibid at 388-98.

${ }^{50}$ In somewhat different formulations this view is expressed in Nicholas J McBride, 'Duties of Care-Do They Really Exist' (2004) 24 Oxford J Legal Stud 417 at 426, 429; Stevens, supra note 38 at 630-31; c.f. McInnes, supra note 5. 
law are not. ${ }^{51}$ This practice, importantly, is not the result of the ease of access to judicial decisions in English, because American court decisions (and American legal scholarship) are treated differently from decisions from the rest of the English-speaking world. Likewise, divergences between English law and American law are not considered a cause for alarm in the way that divergences between English and Australian or Canadian courts are. ${ }^{52}$ From the other direction, American courts do not usually care about legal developments in common law jurisdictions outside the U.S, and most American legal academics are similarly uninterested in non-U.S. law and legal scholarship.

The political significance of all this has not been fully appreciated. For the doctrinal scholar the experiences of other common law jurisdictions do not merely provide a host of examples and ideas. Rather, the common law is in some deep sense a single legal system that adheres to the same principles. And this conception of transnational common law is significant because it provides support to the idea of the common law as non-political. The Commonwealth countries are spread all over the globe and despite shared historical origins, they are now independent political entities. If their common law is common, this can only be because that law is governed by a set of autonomous rules that transcend politics. This is the exact corollary of the Birksian view that there are some correct principles of unjust enrichment that common law courts and commentators are working together to identify. Appealing to the law of another country is illegitimate abdication of sovereignty if laws are a reflection of a political view; if, on the other hand, law is perceived as a matter of expertise achieved through the elucidation

${ }^{51}$ Stevens, supra note 50 at 630, calls doctrinal divergences among common law jurisdictions 'disturbing.' By contrast influences from non-common law jurisdictions with which Britain is in formal political union are treated as alien and undesirable. See McBride, supra note 50 at 439-40; Stevens, supra note 38 at 341-47. Similarly, the Quebec Civil Code-a law of one of Canada's provinces-seems to interest many Anglophone Canadian private lawyers less than new cases coming from Australia or England.

52 It is easier perhaps to see how distinct this view of the common law as something that transcends political and jurisdictional boundaries when contrasting it with the view that conceives of every legal system's laws as reflecting its nation's volksgeist. See Frederick Charles von Savigny, Of the Vocation of Our Age for Legislation and Jurisprudence (Abraham Hayward trans., 1831) at 24-28. In the latter the law (the ius commune, literally the 'common law') emerges from the 'people' and thus cannot be properly transferred to other nations. 
and refinement of law's autonomous principles, then such worries are misplaced. For proponents of this view the combined efforts of judges and lawyers in these jurisdictions are the proof, and the guarantee, that private law remains distinct from politics.

This attitude explains both why Commonwealth lawyers find American law a less appropriate source for citation, and why Americans, in turn, are reluctant to cite the cases of other jurisdictions. From the Commonwealth lawyer's perspective American decisions are less 'eligible' for citation exactly because law in the U.S. is more self-consciously political. As such it is difficult to see it as belonging to the same ideal of non-political law. ${ }^{53}$ Thus, while the citation of an Australian decision by an English court in some sense strengthens the sense of law as a non-political domain, the citation of American decisions has the opposite effect by tainting the non-political purity of Commonwealth common law.

For their part, American lawyers are much less willing to look to other jurisdictions for inspiration or ideas. This reluctance is found across the board: contract and tort are no different from constitutional or administrative law; and common law jurisdictions are no different in this regard from civil law jurisdictions. If all law is in some sense the product of politics and the means for promoting political ends, then reliance on the law of another country is prima facie illegitimate. Already in The Federalist Papers James Madison wrote that 'neither the common nor the statute law of [England], or of any other nation, ought to be a standard for proceedings of this [nation], unless previously made its own by legislative adoption, ${ }^{, 54}$ that is

${ }^{53}$ More precisely, the move away from doctrinal scholarship and a non-political view of law has begun around the 1940s. It is therefore not uncommon to see citation to American materials from that period. This is particularly true in the area of unjust enrichment, where much of the impetus for the modern development came from the U.S. Until the 1930s American courts used to regularly cite English cases, but around this time citation to non-U.S. cases begins to decline. See Lawrence M Friedman et al, 'State Supreme Courts: A Century of Style and Citation' (1981) 33 Stan L Rev 773 at 798-99 (showing a steady decline in the citation of English law by American courts); William H Manz, 'Citation Practices of the New York Court of Appeal' (1995) 43 Buff L Rev 121 at 132-35 (noting the decline in citation of British and other English-language cases beginning in 1930 and the trend toward citation only of old cases).

${ }^{54}$ Lawrence Goldman, ed, The Federalist (Oxford: Oxford University Press, 2008) at 209 (No. 42, by James Madison). After an initial flurry of 'national' American law, there was a move back in the other direction, towards a formalistic or 
unless it has been accepted in a process that guarantees its political legitimacy. Consequently, law should reflect the political values and culture of the jurisdiction in which it was created. ${ }^{55}$ Indeed, even when agreeing on substantive outcomes with some other jurisdiction, the idea that American lawyers should aim to align their law with that of countries, or that they have some cause for concern if it does not, would strike many of them as preposterous. ${ }^{56}$

\section{The Effects of the Relationship between Law and Politics on Restitution Law and Scholarship}

The last section has taken us very far afield. It is time to go back to the discussion with which we started. Recall that we were trying to explain two questions, not just one: first, why restitution law does not play a significant role in American law; and second, why American scholars did not develop much theoretical work on restitution along the lines of the scholarship that now dominates American work on tort or contract law. I hope that at least the outlines of the answer should by now be reasonably clear. In sections (a) and (b) I discuss it in more detail and explain in what ways it is different from the answer given by Saiman and Langbein. Sections (c) and (d) explain two additional puzzles: first, I consider those issues on which one does find some work on restitution by American scholars and explain why Commonwealth doctrinal scholars have been largely silent or dismissive

scientific approach to law. See Gordon S Wood, The Radicalism of the American Revolution (New York: Vintage, 1993) at 322-24, who describes the 'most dramatic institutional transformation in the early Republic,' where 'law became more and more of a science removed from politics.' During this period English and American law were thought very similar. See e.g. AV Dicey, 'A Common Citizenship for the English Race' (1897) 71 Contemporary Rev 457 at 469-71. Erie Railroad, supra note 45 , is a useful signpost for the re-emergence of earlier approach.

${ }^{55}$ See e.g. Richard A Posner, How Judges Think (Cambridge: Harvard University Press, 2008) at 351-52 ('To cite foreign law as authority is to suppose fantastically that the world's judges constitute a single community of wisdom and consciences'); John O McGinnis, 'Foreign to Our Constitution' (2006) 100 Nw. U L Rev 303 at 311-12, 327-28.

${ }^{56}$ So much so that at the time of writing legislators in 'more than two dozen states have considered measures' banning judges from consulting 'Shariah, or foreign and religious laws more generally.' Andrea Elliott, 'The Man Behind the Anti-Shariah Movement,' The New York Times (31 July 2011) Al. 
about them; and second, I offer an explanation of existing debates among restitution scholars in the Commonwealth, which are often presented as competing attempts to explain the 'nature' of restitution, but which I believe are better understood as reflecting different views on the relationship between law and politics.

\section{(a) Explaining the Difference between American and English Attitudes to Restitution}

With some simplification the view I associated with English law can be summarized syllogistically as follows:

(1) Law and politics, properly understood, are mutually exclusive.

(2) Therefore a political answer to a problem is, by definition, not a legal one.

(3) Abolition of entrenched doctrines is a political kind of change.

(4) Therefore it is one that only the legislature can bring about.

(5) Therefore, it is one that is unavailable to the lawyer.

This forms part of the worldview, or what I called earlier the ideology of the English legal system, against which restitution lawyers were working. Nonetheless, faced with situations where existing legal categories resulted in outcomes that were deemed unjust but based on 'trite law' that seemed beyond change, a legal solution was sometimes felt to be needed. Restitution provided the answer, and it proved particularly useful because it has at its core an element that allows for its unlimited expansion. The most important element within the unjust enrichment model is that of an 'unjust factor.' A successful plaintiff must be able to show that the defendant's enrichment at her expense falls under of several recognized unjust factors or else her claim will fail. The list is made up of a hodgepodge of considerations that have little in common especially once we account for the so-called 'policymotivated' unjust factors. ${ }^{57}$ Within the alternative civilian analysis (embraced by Birks shortly before he died) and favoured in certain Commonwealth jurisdictions (most prominently Canada), what needs to be shown is lack of legal basis, a notion that is equally open-ended. ${ }^{58}$

Thus, the very feature that makes unjust enrichment attractive-its ability to keep the law in line with common sense morality-is what makes it

\footnotetext{
${ }^{57}$ See Burrows, supra note 18 at 480; Birks, supra note 16 at 193-202, 304-08.

${ }^{58}$ C.f. Lionel Smith, "The Mystery of "Juristic Reason" (2000) 12 Sup. Ct L Rev (2d) 211 .
} 
a potential threat to the entire doctrinal edifice, and the separation of law from politics. One sees this tension in debates among English lawyers about the principle of unjust enrichment. For a long time there was resistance to the idea that such a principle was part of the common law: one judge described it as a 'well-meaning sloppiness of thought,"59 and as late as 1977 we were told by the House of Lords that a general principle of unjust enrichment (as opposed to 'specific remedies in particular cases') is not recognized in English law. ${ }^{60}$ These sceptics were not opposed to some of the doctrines now subsumed under this heading (such as the doctrine that the recipient of a mistaken payment ought to give it up), but rather to the introduction of a category, which despite good intentions, was not sufficiently constraining. In terms of the present discussion the perceived danger was that unjust enrichment's doctrinal open-endedness would bring down the separation of law from politics. It is exactly for this reason, therefore, that the defenders of unjust enrichment have been so insistent that unjust enrichment, despite appearances, has little to do with justice, and why they tried to show just how much the law has shed its older loose and vague formulations to become a doctrinally respectable area in which "the judges simply ask themselves "is this enrichment unjust?", and this question is determined as 'a matter of law' ${ }^{61}$ Many of the seemingly purely doctrinal debates in this area of law are, in part, a reflection of this tension between the desire to keep the doctrine loose enough to serve the role of solving problems in other areas of law but not too loose as to undermine its doctrinal respectability.

If I am right about this, then it is not difficult to see why restitution law (and the principle against unjust enrichment) played a much more significant role within English (and Commonwealth) law than it has in American law in the last fifty or so years. The primary motivation for unjust enrichment law was a felt need to circumvent various doctrines that were thought to lead to unjust results but were also considered too entrenched to eliminate. Unjust enrichment was new and thus sufficiently malleable, and it was perhaps inherently somewhat looser than other areas of law. It could be

${ }^{59}$ Holt v Markham [1923] 1 KB 504 at 513, CA; c.f. Baylis v. Bishop of London [1913] l Ch 127 at 140, C.A. (criticizing the appeal to equitable doctrines grounded in "vague jurisprudence which is sometimes styled "justice as between man and man."').

${ }^{60}$ Orakpo v Manson Investments Ltd [1978] AC 95 at 104, HL (Eng).

${ }^{61}$ Burrows, supra note 18 at 26, 86. 
applied to a much broader range of situations than either tort or contract. And with sufficient doctrinal work it was considered sufficiently 'legal' to assuage fears of the politicization of private law. ${ }^{62}$

The American story is different. To the extent that American courts and academics were still trying to maintain the separation of law from politics, they still had some use for restitution, although even here they were probably less concerned with precedent or doctrinal constraints than their English counterparts. (It is therefore not a coincidence that this doctrinal innovation was imported into Commonwealth law from the United States.) But as the idea of law being separate from politics was largely abandoned, so was the interest in the reasoned elaboration of doctrine. American courts still continued to base their judgments on traditional doctrinal materials (even though they have always been much more sympathetic to academic work than English courts), ${ }^{63}$ but they did so while openly acknowledging the underlying normative considerations at stake, and they showed greater willingness to abandon old doctrines that did not seem fitting to changing times. Thus, for instance, in the U.S. the solution to the problem of the battle of the forms mentioned above was achieved by changing the rules on offer and acceptance and was classified as part of contract law. The famous section 2-207 of the Uniform Commercial Code maintains that under

62 There is a corresponding story highlighted by the somewhat different path taken by Australian law. The Australian High Court has interpreted the founding cases of unjust enrichment as cases of equity. See Roxborough $v$ Rothmans of Pall Mall Australia Ltd, [2001] HCA 68, 208 CLR 516 I 75-86 (Gummow J., concurring), endorsed by a unanimous courts in Farah Construction Pty Ltd $v$ Say-Dee Pty Ltd, [2007] HCA 22, 81 ALJR 1107 I 148-154 and Bofinger v Kingsway Group Ltd, [2009] HCA 44, 239 CLR 269 I 88-98. The response of most unjust enrichment scholars, especially from England, has been highly critical. See e.g. Burrows, supra note 18 at 43 (arguing that the Australians are condemned 'to flounder in the dark ages where "equity" is somehow regarded as an illuminating "doctrinal basis" for decisions'). The reason is clear: equity poses the very same threats to the politicization of the law that defenders of unjust enrichment have worked hard to dispel with their detailed doctrinal work on law. See Birks, supra note 5 at 20-22; Birks, supra note 34 at 16-17, 22; Peter Birks, Book Review of Meagher, Gummow and Lehane's Equity Doctrines and Remedies, 4th ed. (Chatswood: Butterworths LexisNexis Australia, 2002), (2004) 120 Law Q Rev 344 at 345 (complaining about a discussion grounded in concepts that are 'as vague and unstable ... as could well be found').

${ }^{63}$ See Neil Duxbury, Jurists and Judges: An Essay on Influence (Oxford: Hart, 2001) at 24-33. 
certain conditions a contract may be formed even when the acceptance is in a form that introduces changes to the offer. Similar ideas were adopted long before by the courts. ${ }^{64}$ And even if courts had to base their judgments on doctrine, there was no reason for academics to constrain themselves in this way. American legal academics have come to see themselves as engaged in normative debates on what the law should be, and on these matters doctrine has come to be perceived as a somewhat sinister means of obscuring the real (normative, political) issues at stake. It was thus difficult to see how engaging in doctrinal scholarship could provide real help in addressing the issues the courts face. ${ }^{65}$

All this only makes the question posed in the beginning even more pertinent. If American law is much more concerned with engaging people with moral and political questions, why did American academic lawyers not turn to normative, 'theoretical' work on unjust enrichment in the way they did with contract or tort law? The answer should by now be clear: unjust enrichment law was a product of the particular need to solve legal problems in a particular way. It was a solution to an essentially legal problem, but those who were no hampered by this problem, had relatively little need for it. If it is accepted that a main role of unjust enrichment law was to solve problems in other areas of law, the American lawyer's response would more likely have been: let's change the original law. Why add a layer of doctrinal complexity, when the source of the problem can be removed more directly? Even if the courts sometimes marched to a similar beat as their Commonwealth counterparts, ${ }^{66}$ for academics, there was simply no intellectual problem to

${ }^{64}$ See Douglas G Baird \& Robert Weisberg, 'Rules, Standards, and the Battle of the Forms: A Reassessment of \$2-207’ (1982) 68 Va L Rev 1217 at 1233-35.

${ }^{65}$ David Robertson recounts interviews with an anonymous law lord who said 'the trouble with Denning was that he cheated.' David Robertson, Judicial Discretion in the House of Lords (Oxford: Clarendon Press, 1998) at 74. This suggests that that judge may have been perfectly happy with the outcome Denning had reached, but still critical of the way he ignored doctrinal constraints. By Contrast, in the American context, the prevailing attitude is almost the opposite: it is considered cheating to hide one's political decision behind the veil of supposedly neutral doctrine. See Posner, supra note 55 at 371-72. Posner's remark-'How anomalous Lord Denning seemed among modern English judges; how at home he would have been in an American court system,' is surely correct. Richard A Posner, Law and Legal Theory in England and America (Oxford: Clarendon Press, 1996) at 31 n.76.

${ }^{66}$ I say 'sometimes' advisedly. Even here the willingness to depart from established doctrine is much more easily established. See for example, the fate of the 
solve. If some doctrines pose a problem, well, 'Off with their heads!' At the higher level of theoretical abstraction, unjust enrichment could not add much to the discussion on the appropriate boundaries of property rights, on what is considered a 'taking,' on the normative implications of autonomy, fairness, or efficiency, but by and large the principle of unjust enrichment was not perceived as helpful in addressing them. In other words, the reason there was relatively little non-doctrinal unjust enrichment scholarship was that it was not perceived to have much non-doctrinal intellectual meat.

\section{(b) The Place of Legal Realism}

Superficially, all this fits the realist story told by Saiman and Langbein. Many of the realists denounced the kind of conceptualism that is a token of doctrinal scholarship. Felix Cohen, most famously, scathingly attacked the idea that there is some conceptual truth to be discovered about legal questions. ${ }^{67}$ 'Title' was one of his examples of 'legal nonsense,' a view he shared with Karl Llewellyn who thought legal title was a 'mystical' idea. ${ }^{68}$ Less famously, but just as importantly, Cohen attacked the idea that legal criticism is in some sense based on logic: the only significant basis for legal criticism, he said, was that the law was morally wrong. ${ }^{69}$ Such a view often translates to contempt towards what is sometimes called 'juridical reason,' especially if one believes that legal doctrine alone cannot provide a very

constructive trust in American law as discussed in Dagan, Restitution, supra note 10 at 305-08; Andrew Kull, 'Deconstructing the Constructive Trust' (2004) 40 Can Bus LJ 358. For a more general discussion see section IV.(d) below.

${ }^{67}$ See Felix S Cohen, 'Transcendental Nonsense and the Functional Approach' (1935) 35 Colum L Rev 809. There are of course many others who have made similar claims. Contrast this with Birks, supra note 40, at 98-99 ('We have not yet succumbed to the realist destruction of legal science. ... The challenge is to defend the common law against the politicising post-realists...'); c.f. Birks, supra note 16 at 19 ('judges cannot be expected to pass upon ... questions [of justice]. Indeed the wonderful freedom which we call moral pluralism depends to some extent on their not being asked to do so.').

${ }^{68}$ Cohen, supra note 67 at 820; accord KN Llewellyn, "Through Title to Contract and a Bit Beyond' (1938) 15 NYULQ Rev 159 at 165 (internal quotes omitted).

${ }^{69}$ See Felix S Cohen, ‘The Ethical Basis of Legal Criticism' (1931) 40 Yale LJ 201. 
strong constraint on a judge's ability to get to the outcome she wants. This, famously, is also something that many legal realists believed. ${ }^{70}$

In truth, however, the story is more complex, because to the extent that legal doctrine is nowadays less important in the United States than in England, putting the blame (or the praise) on the realists ignores the background described above about law and politics. As I see it, the realist attack on legal concepts is grounded in a particular view about the relationship between law and politics. It is grounded either in rejection of the view that legal rules are there to keep lawyers and political considerations apart, or in the view that if that is the aim of legal rules, they fail miserably in this task. On this point, I believe, the legal realists, or more precisely their success and lasting influence in the United States, are the effect, not the cause. Put differently, to invoke the legal realists' dislike for doctrinal scholarship as the reason for American lawyers' lack of interest in contemporary doctrinal work on restitution is not to offer an answer to the question, but merely to restate it. What must be explained are the origins of legal realism, and, especially in a comparative context, why its disparate impact in different jurisdictions. The question is not, or not only, why legal realism emerged in the United States and not elsewhere. The answer to this question involves various intertwining factors, having to do with the earlier professionalization of American universities, the early emergence of the American law school as an integral part of the university system, and a 'revolt against formalism ${ }^{71}$ that crossed disciplinary boundaries in American universities at the time. But we should not forget that broadly similar realist ideas emerged in many countries around the same time: in France François Gény and Léon Duguit expressed such views, in Germany there was Jhering and later the 'free law' movement, ${ }^{72}$ and in Scandinavia there was a parallel 'realist' movement to the American one. ${ }^{73}$ In fact, even England had its small

${ }^{70}$ See Karl N Llewellyn, 'Remarks on the Theory of Appellate Decision and the Rules or Canons about How Statutes are to Be Construed' (1950) 3 Vand L Rev 395.

${ }^{71}$ This is the central theme of Morton White, Social Thought in America: The Revolt against Formalism, new ed. (Boston: Beacon, 1957).

${ }^{72}$ On this group's influence on the legal realists see James E Herget \& Stephen Wallace, 'The German Free Law Movement as the Source of American Legal Realism' (1987) 73 Va L Rev 399.

${ }^{73}$ For a short summary see Jes Bjarup, 'The Philosophy of Scandinavian Legal Realism' (2005) 18 Ratio Juris 1. 
band of 'legal realists' working around the same period that the American legal realists came to prominence. ${ }^{74}$

The significant question is why despite all this, realist ideas have had much greater staying power in the United States, where they have taken deep root and have affected the way law is taught, researched and conceived, but have had much weaker impact elsewhere. In the context of this essay the interesting question is why, even after being shown the American example, most English scholars remained not just unenthusiastic, but often openly hostile to legal realism. Such questions obviously do not lend themselves to a single, simple answer, but I believe an important ingredient in the answer has to do with the different perceptions already existing (or emerging) at the time on the respective roles of and relationships between law and politics in the American and English (or British) political traditions. ${ }^{75}$ Realist ideas caught on in the United States because the periods prior to their emergence saw more overt ties between law and politics, especially, but not exclusively, in constitutional law. While it is true that on the surface most legal realists seemed relatively unconcerned with the question of the relationship between law and politics and with the impact of judges' political opinions on the outcome of cases, ${ }^{76}$ I think it is this background that made realist ideas appear a more adequate, and a more honest, description of the law. Then, in a kind of feedback loop mechanism, legal realism may have made the

${ }^{74}$ The best known British 'realists' were Laski and Jennings. See generally Cyril Glasser, 'Radicals and Refugees: The Foundation of the Modern Law Review and English Legal Scholarship' (1987) 50 Mod L Rev 688 at 693-703.

${ }^{75}$ I therefore cannot fully accept Duxbury's claim that analytic jurisprudence has been a success story in England primarily because it 'satisf[ied] the epistemic requirements of late-Victorian university culture.' Neil Duxbury, 'Why English Jurisprudence Is Analytical' (2004) 57 Curr Legal Probs 1 at 46. Similar trends towards greater professionalization and scientism were central to the rise of American universities, where, if anything, they were more pronounced. And yet, a few exceptions aside, analytic jurisprudence never caught on in U.S. law schools to the same degree it has influenced English law schools. What I say in this essay helps, I think, to understand why. Austin's universal analytic approach fits well the English political tradition, the minimalist role for law in it, and the view that law embodies some general cross-jurisdictional principles. It fits much less well the more political (and hence local) conception of law in the U.S.

${ }^{76}$ One finds only occasional remarks to that effect. See See Karl N Llewellyn, 'Some Realism about Realism-Responding to Dean Pound' (1931) 44 Harv L Rev 1222 at 1237; Llewellyn, supra note 69 at 175 n.25; Cohen, supra note 67 at 845. 
connection between law and politics even more pronounced, until it was made explicit by scholars writing a generation later. ${ }^{77}$

In one sense this claim will not come as news to lawyers: the differences between the two countries in matters like parliamentary sovereignty, judicial review, judicial engagement in politically-sensitive matters and so on are all too obvious to ignore. But acknowledgement of these differences is usually limited to public law. The point emerging from my account is that this is a mistake. They are relevant to private law, because in a fundamental way they are relevant to the very understanding of what counts as private law, and perhaps more importantly to the question why something counts as private law. In fact, the very distinction between private law and public law should be understood as a product of the English view on the relationship between law and politics, not as its source. By contrast, the very different conception of the relationship between law and politics which explains why American lawyers have long considered the distinction between private and public law suspect. $^{78}$

I might still be challenged that what looks like a great divide is only a mirage, a reflection of the particular (or peculiar) interests of American academic lawyers. According to this view on both sides of the Atlantic lawyers rely on restitutionary ideas in roughly equal measure, but it is American legal academics' lack of interest in doctrinal questions that obscures the rather similar state of the law. ${ }^{79}$ There are several responses to this suggestion. First, even if it is entirely true, we are still left with a puzzle-although perhaps a less significant one-and that is why American academic lawyers are relatively uninterested in writing on this area of law as opposed to their English and Commonwealth counterparts. Second, despite the greater divide between legal practice and academic law in the United States, there is an inevitable connection between them. Those who end up in legal practice get their first legal training in law school, and if one does not encounter unjust

77 See e.g. Martin Shapiro, 'Political Jurisprudence' (1964) 52 Ky LJ 294 at 29495 (arguing that 'political jurisprudence' is a continuation of 'judicial realism'); David E Ingersoll, 'Karl Llewellyn, American Legal Realism, and Contemporary Legal Behavioralism' (1966) 76 Ethics 253 at 253-54.

${ }^{78}$ For famous examples of this attitude see Morris R Cohen, "The Basis of Contract' (1931) 46 Harv L Rev 533 at 585-92; Robert L Hale, 'Coercion and Distribution in a Supposedly Non-Coercive State' (1923) 38 Pol Sci Q 470; c.f. Roscoe Pound, 'Mechanical Jurisprudence' (1908) 8 Colum L Rev 605 at 614, passim.

${ }^{79}$ I am grateful to Paul Mitchell for this challenge. 
enrichment there, unjust enrichment may just not be part of the conceptual toolbox she uses later in practice. Third and most important, virtually all of those who have considered the U.S.-Commonwealth divide on unjust enrichment have concluded that the differences are found not only in the law reviews, but also in the law reports.

\section{(c) Where Has American Law Seen Developments in Restitution?}

To further develop the point just made, I will return now to a matter that has so far has only been briefly alluded to, but which I think fits the story told here very well, and that is that there is actually some American scholarship that invokes restitutionary ideas, but this work is very different from the English and Commonwealth doctrinal work on unjust enrichment. For this we need to distinguish between a cause of action in unjust enrichment and restitutionary (gain-based) remedies. As a cause of action unjust enrichment is discussed by American lawyers primarily in those areas in which it is thought that existing legal doctrine contains a gap thought incapable of addressing an existing injustice. To put the matter in somewhat rough terms, whereas in English law unjust enrichment has been developed as a distinctly legal supplement for solving problems with existing doctrines in other areas of law that lawyers felt incapable of solving within those areas of law, for American lawyers the main use for restitutionary ideas has been the development of new grounds for liability where none existed before. Claims for reparation for historical wrongs are a primary example. ${ }^{80}$ Central to this understanding of unjust enrichment is the view that the soul of unjust enrichment ... includes flexibility, creativity, justice and morality underpinnings, and discretion. ${ }^{81}$ It should not come as a surprise that doctrinal English lawyers who relied on restitution primarily for correcting problems with existing doctrines in other parts of private law have not been

${ }^{80}$ More recently it has been suggested that unjust enrichment could help those hit in the recent mortgage crisis See Peter Linzer \& Donna L Huffman, 'Unjust Impoverishment: Using Restitution Reasoning in Today's Mortgage Crisis' (2011) 68 Wash \& Lee L Rev 949.

${ }^{81}$ Roberts, supra note 11 at 1028. In fact, Roberts criticizes the new Restatement for not sufficiently recognizing the "[b]eauty ... in the ability of restitution doctrine to adapt and aid cases with unusual fact patterns and unforeseen circumstances.' Ibid at 1044 . Contrast this with the views described in the text accompanying notes 16-18 above. 
enthusiastic about extending restitution in that direction. ${ }^{82}$ One such critic has even contrasted doctrinal scholars' commitment to the 'principle of unjust enrichment' with the 'politics' that underlies the restitutionary ideas he found in the United States. ${ }^{83}$

The other area where we have seen some American interest is the question of restitution as a remedy, and this too is consistent with the view I outlined above. Within the approach favoured by Commonwealth lawyers, there is a conceptual connection between particular types of claim and particular remedies, and as a result the area of remedies has remained relatively undeveloped. In American law, there was a reversal of roles. The content of one's rights (or, as they became more neutrally to be called, 'entitlements') has come to be seen as determined by the remedies one could get for their violation. This led academic lawyers to explore the question of remedies at levels of sophistication unmatched by (and largely unknown to) Commonwealth lawyers. ${ }^{84}$ And it is here that the possibility of a remedy based on the defendant's gain rather than the plaintiff's loss (as opposed to the question whether there is a distinct domain of 'unjust enrichment'), has attracted some attention. But this attention is likely to disappoint friends of unjust enrichment: the question of whether there is room for gain-based remedies is one that can be raised alongside a broad range of remedies that could all be attached to different claims, whether these are classified as belonging to contract, torts, patent violation, 'unjust enrichment,' or anything else. Therefore, the sort of arguments utilized in deciding whether to award or withhold such remedies are analyzed largely in consequentialist terms and touch on considerations that English proponents of unjust enrichment are likely to consider alien to the subject. ${ }^{85}$

${ }^{82}$ See McInnes, supra note 5 at 126-30; Monica Chowdry \& Charles Mitchell, 'Responding to Historic Wrongs: Practical and Theoretical Problems' (2007) 27 Oxford J Legal Stud 339.

${ }^{83}$ McInnes, supra note 5 at 145.

${ }^{84}$ The work that launched a thousand articles is Guido Calabresi \& A Douglas Melamed, 'Property Rules, Liability Rules, and Inalienability: One View of the Cathedral' (1972) 85 Harv L Rev 1089.

${ }^{85}$ See e.g., General Electric Capital Corp v Central Bank, 49 F 3d 280 (7th Cir, 1995), criticized in McInnes, supra note 5 at 129; and see other similar cases criticized in Saiman, supra note 17 at 523-25. 
Saiman notices this point and ascribes this break between rights and remedies to legal realism. ${ }^{86}$ Loosely speaking, the connection is correct, although once again the picture is more complex. ${ }^{87}$ Here too I think a more complete explanation has to include the main thesis of this essay about the location of law with regard to politics. The view that sees a conceptual connection between certain legal rights and certain legal remedies is apolitical to the extent that it denies that available legal remedies should be determined according to normative judgments external to legal concepts. Birks provided a clear statement of this view in the context of considering the issue of priority among creditors in insolvency. He rejected the view that this matter should be determined by an attempt at assessing which solution would lead to better consequences. As he put it, '[f] or my part I find it difficult to say who deserves to suffer or which groups deserve to suffer more than others. Giving an answer to changing the answer already given seems to be precisely the kind of issue which has to be left to the legislature. ${ }^{88}$ These are the sort of considerations that a political body should take, and as such they are beyond the remit of legal argument. According to the approach Birks favoured the business of the lawyer can only be to say with as much precision as possible on what facts proprietary interests arise. ${ }^{, 89}$ This view makes much sense as both a statement of the separateness of law and politics, and as a strategy for keeping them like that.

Understanding rights in terms of remedies-understanding legal entitlements as the sum total of the remedies they can give rise to-is easier to accept when law is understood in broadly political terms. On this view the appropriate remedy is not determined by its 'form,' by correct location of the event in question on the legal 'map.' Instead, legal rights are thought of as nothing more than entitlements to certain legal protections, and the limits of those legal protections are determined by political considerations that legal doctrine cannot provide. This does not necessarily mean that judges will

${ }^{86}$ Saiman, supra note 8 at 1031 ("American lawyers are less outraged by the idea that courts have substantial authority to craft appropriate remedies').

${ }^{87}$ The one name Saiman mentions in this context is Lon Fuller, someone who was never considered among the ranks of the realists, and in fact authored one of the first critiques of legal realism. See LL Fuller, 'American Legal Realism' (1934) 82 U Pa L Rev 429.

${ }^{88}$ Peter Birks, 'The Law of Restitution at an End of an Epoch' (1999) 28 UW Austl L Rev 13 at 55 (1999) (emphasis added).

${ }^{89}$ Ibid at 56. 
always undertake a detailed cost-benefit analysis in search of the optimal remedy in every individual case. They may not have the means or data to do that (and it is here that legal scholars may come to their aid); but it does mean that there is no principled argument against, say, taking deterrence considerations into account when deciding whether to award restitutionary remedies or not, and it does mean that in practice, remedies will be subject to the impact of political argument unmediated by legal form. From a doctrinal perspective this is conceptual confusion and a dangerous development in that it undermines the division between law and politics. From the opposite perspective, legal categories are tools to be used for the sake of promoting normative goals. This is precisely the approach one finds much more often among American restitution scholars and American courts. $^{90}$

\section{(d) A Note on the Debates among Restitution Lawyers}

The argument developed above was mainly focused on the difference in modern attitudes to restitution in England (and to varying degrees the rest of the Commonwealth) and the United States; but I think it can also help us understand existing debates among English (and Commonwealth) restitution scholars. Those are often presented as debates about the 'nature' of restitution or of the common law. On one side stand those who adopt the broadly Birksian position, who insist on the reality of unjust enrichment, and on the other stand the unjust enrichment sceptics, some of whom doubt whether this area unjust enrichment law even exists. Consider, once again, the case of mistaken payment. The question-whether the recipient should give up the money received-is simple, as is the legal outcome. The competing explanations offered as to why are, nonetheless, very different, although they too are not very difficult to understand. Where, then, does all the disagreement come from?

One characteristic aspect of the debate, at times amusing but more often frustrating, is the disparity in the kinds of arguments used and the sources

90 See generally Dagan, Restitution, supra note 10. Dagan is, unsurprisingly, unenthusiastic about the 'unjust enrichment' label, see ibid at 25-26, and explicitly identifies his subject as concerned with gain-based remedies. See ibid at 26 ('I suggest viewing unjust enrichment as a loose framework.... By a loose framework I mean a mere placeholder for arranging and classifying legal rules that involve benefit-based liability or benefit-based recovery and that-for whatever reason-do not find a comfortable home in another field.'). 
used to substantiate them. Proponents of the proprietary approach often invoke broadly moral and political considerations; their respondents then answer by appealing to cases. ${ }^{91}$ Each side finds the other's way of arguing for their outcome puzzling. This difference becomes less puzzling once it is realized that the two sides to the debate are committed to different views on the proper way of developing and improving the law. I am confident that if the matter were to be examined empirically, it would be found that there is strong correlation between those who think that unjust enrichment is a real legal category and the view that the development of law must be based on the analysis and elaboration of legal materials, whereas those who are critical of unjust enrichment tend to the view that law must primarily be explained and justified by appeal to external moral standards. For those in the second group the fact that one can find cases that mention unjust enrichment is largely irrelevant to the question whether unjust enrichment 'exists.' In considering the structure of the law our primary consideration is matching the law not with doctrine, but with moral and political principles. From this perspective, the principle of unjust enrichment appears largely superfluous.

So here we have one important moral for those engaged in the debates on the status of unjust enrichment: until you agree on the question of law and politics, the likelihood of one side adducing arguments that the other is likely to find potentially convincing, or even relevant-the likelihood, in other words, of genuine debate-is small indeed. Since it is unlikely that an answer to this question will be forthcoming any time soon, the question of the 'nature' of unjust enrichment is likely to remain equally contested.

\section{Conclusion}

In most comparative discussions English and American law are still treated as belonging to one 'family,' one legal tradition, one that in fact is quite often called the 'Anglo-American' legal tradition. In some respects no doubt the classification is still valid and valuable, but on some issues it can be misleading. The question considered in this essay is one of those. The explanation offered here for their divergence on unjust enrichment is that

${ }^{91}$ Consider: 'whatever the position Hedley's attacks on the unjust enrichment school of thought first started, the judicial tide of opinion has turned in favour of explicitly applying the unjust enrichment principle.' Burrows, supra note 18 at 35. I suspect those in the other group will not consider this argument relevant, let alone decisive. 
answering this question requires not simply stating that doctrinal scholarship has become much less popular in the U.S. than in England, but rather explaining why this happened. The answer offered here is, first, that largely through the work of doctrinal scholars restitution law has come to occupy in English law the role of resolving problems in areas in which legal doctrine seemed to lead to unjust results but was thought too deeply entrenched for change. It then argued that such ossification of doctrine was possible because of a particular conception of the common law as non-political, one that in turn was believed to impose certain limits on the sort and scope of legal change courts can bring about. The rise of unjust enrichment in English law was, then, explained as a solution to an internal legal problem that is the result of the normative foundations of English law and its conceptualization in relation to politics. It is this conceptualization that has been largely abandoned in the United States, and with its demise the need for developing unjust enrichment as a distinct legal category declined as well. This fact itself has a complex relationship with legal realism, but my argument has sought to show that it cannot be fully explained as caused by legal realism; rather, at least to some extent it predates it and is better understood as one of the causes of legal realism, or rather of its lasting success.

The essay has also touched on more abstract questions, of which I wish to highlight two. One is the question of the relationship between law and politics. It should be clear that I reject the view that these two domains are as a conceptual matter separate just as much as I reject the view that as a conceptual matter they are tied. Rather, as I have sought to show my view is that there are various ways of understanding their relationship resulting in different understandings of what law is. The other is the divide that exists in legal philosophy between the search for what is called, misleadingly I think, 'the nature of law' on the one hand, and the theoretical questions relating to particular areas of law on the other hand. The former inquiry is typically presented as conceptual and morally neutral whereas the latter as normative, and as such the two seem to be relatively independent of each other. I reject this this divide, because I believe both should be understood as part of one political inquiry. As the present essay has shown normative choices at the level of the 'nature' of law have normative implications on what particular areas of law look like. 